\title{
Competition After Unbundling: Entry, Industry Structure, and Convergence
}

\author{
George S. Ford \\ Phoenix Center for Advanced Legal \& Economic Public Policy Studies \\ Thomas M. Koutsky \\ Phoenix Center for Advanced Legal \& Economic Public Policy Studies \\ Lawrence J. Spiwak \\ Phoenix Center for Advanced Legal \& Economic Public Policy Studies
}

Follow this and additional works at: https://www.repository.law.indiana.edu/fclj

Part of the Administrative Law Commons, Antitrust and Trade Regulation Commons, Communications Law Commons, and the Legislation Commons

\section{Recommended Citation}

Ford, George S.; Koutsky, Thomas M.; and Spiwak, Lawrence J. (2007) "Competition After Unbundling:

Entry, Industry Structure, and Convergence," Federal Communications Law Journal: Vol. 59 : Iss. 2 , Article 4.

Available at: https://www.repository.law.indiana.edu/fclj/vol59/iss2/4

This Article is brought to you for free and open access by the Law School Journals at Digital Repository @ Maurer Law. It has been accepted for inclusion in Federal Communications Law Journal by an authorized editor of Digital Repository @ Maurer Law. For more information, please contact rvaughan@indiana.edu.

\section{$\Psi$}

JEROME HALL LAW LIBRARY

INDIANA UNIVERSITY

Maurer School of Law
Blooming toan 


\title{
Competition After Unbundling: Entry, Industry Structure, and Convergence
}

\author{
George S. Ford, Ph.D.*
}

Thomas M. Koutsky, Esq.**

\section{Lawrence J. Spiwak, Esq. ***}

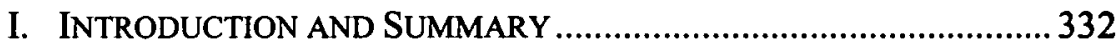

II. INDUSTRY CONCENTRATION IN COMMUNICATIONS MARKETS ... 337

III. AN ENTRY-ORIENTED MODEL OF INDUSTRY STRUCTURE FOR

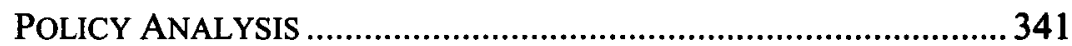

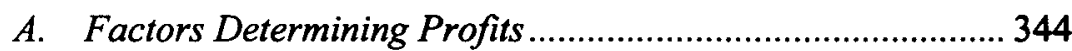

1. Market Size and Entry.....................................................345

2. The Intensity of Price Competition ....................................346

3. Degree of Product Differentiation....................................351

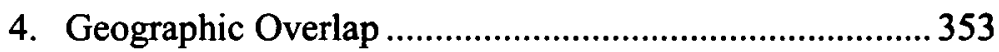

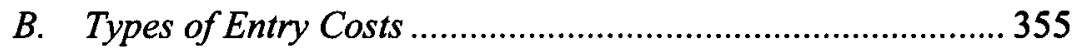

1. Technological Entry Costs ...............................................356

\footnotetext{
* Chief Economist, Phoenix Center for Advanced Legal \& Economic Public Policy Studies; Ph.D., Auburn University, 1988.

** Resident Scholar, Phoenix Center for Advanced Legal \& Economic Public Policy Studies; J.D., University of Chicago Law School, 1991.

*** President, Phoenix Center for Advanced Legal \& Economic Public Policy Studies; J.D., Cardozo School of Law, 1989. A version of this Article was originally published as George S. Ford, Thomas M. Koutsky \& Lawrence J. Spiwak, Competition After Unbundling: Entry, Industry Structure and Convergence, PHOENIX CENTER POLICY PAPER No. 21 (July 2005), available at http://www.phoenix-center.org/pcpp/PCPP21Final.pdf. The views expressed in this Article are the Authors' alone and do not represent the views of the Phoenix Center, its Adjunct Fellows, or any of its individual Editorial Advisory Board members.
} 
2. Strategic Entry Costs........................................................... 356

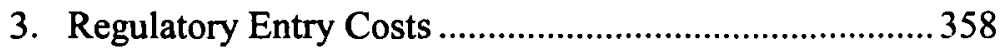

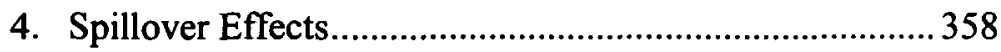

IV. MODERN COMMUNICATIONS POLICY AND THE ENTRY MODEL:

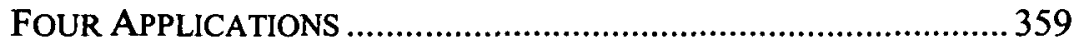

A. Effect of Convergence on Industry Structure ..........................360

B. Market Size and the Deployment of Advanced Communications Networks .................................................. 362

C. Deterring Entry by Treating Entrants and Incumbents

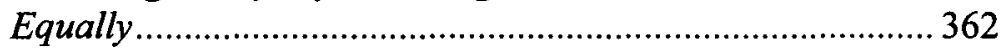

D. What Entry Says About Collusion …………………..................365

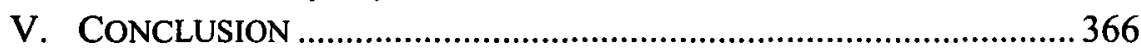

\section{INTRODUCTION AND SUMMARY}

In the last few years, the goal of U.S. telecoms policy has been to promote and rely upon facilities-based "intermodal competition"- that is, competition among network platforms. This approach marks an important change from the initial implementation of the Telecommunications Act of 1996, in which policymakers vigorously enforced various network sharing and unbundling obligations aimed at jump-starting competition through "intramodal" means.

This brave new world of telecoms competition raises very basic and essential questions for policymakers: (1) what will be the market structure of this new "intermodal" market, in which competition is effectively limited to firms that own their own network facilities; and (2) will we be satisfied with the results? In this Article, we provide policymakers with a framework for analyzing this emerging industry structure. The linchpin of our framework is its focus on the entry by new firms and the expansion by existing firms into related markets-i.e., for facilities-based "intermodal" competition to work, entry by new firms should be encouraged, and existing network platforms must be able to expand freely into other markets in which their respective network platforms are capable of serving.

At the outset, it is important for all to understand that facilities-based competition in local communications markets will be characterized by only a few firms. As consistently demonstrated by academic research, given the huge fixed and sunk costs inherent to the construction and commercial operation of communications networks, the equilibrium level of concentration of terrestrial firms in local communications markets (voice, video, and data) will be relatively high. ${ }^{1}$ As we discuss below, fewness

1. Jerry B. Duvall \& George S. Ford, Changing Industry Structure: The Economics of Entry and Price Competition PhOENIX CENTER POLICY PAPER No. 10 (Apr. 2001), 
arises because scale economies and sunk costs limit the number of firms that can profitably serve a market - and local communications networks are notoriously riddled with scale economies and sunk costs. Any policymaker interested in local communications markets should, therefore, start from the assumption that there will, at best, be only a "few" facilities-based firms. The notion that the local market can sustain five to seven local terrestrial networks all offering highly substitutable services is both naïve and unrealistic. ${ }^{2}$ Indeed, a federal policy that relies on facilities-based, intermodal competition in communications markets is a decision to embrace, or at least tolerate, more concentrated industry structures.

But, policymakers should not let the "perfect" become the enemy of the good: competition, even among a few firms, is vastly superior to (even regulated) monopoly. While it is highly unlikely that dozens of local networks or facilities-based competitors could thrive in the communications markets (i.e., various forms of video, voice, and data services), this lack of headcount does not mean that competition is absent or that consumers do not reap substantial benefits from a more limited number of competitors. Indeed, many telecommunications markets deemed substantially competitive are concentrated. In the wireless industry, the Herfindahl-Hirschman Index ("HHI") is nearly 3,000 (the numbers equivalent of three firms), ${ }^{4}$ and in the long-distance market, the three largest firms (AT\&T, MCI, and Sprint) controlled nearly seventy percent of that market in 1999, fifteen years after divestiture and prior to Bell company entry into that market. ${ }^{5}$ Yet, both markets are characterized

available at http://www.phoenix-center.org/pcpp/PCPP10Final.pdf; T. Randolph Beard, George S. Ford \& Lawrence J. Spiwak, Why ADCo? Why Now? An Economic Exploration into the Future of Industry Structure for the "Last Mile" in Local Telecommunications Markets PHOENIX CENTER POLICY PAPER NO. 12 (Nov. 2001), available at http://www.phoenix-center.org/pcpp/PCPP12.pdf, reprinted in 54 FED. COMM. L.J. 421 (2002), available at http:/www.law.indiana.edu/fclj/pubs/v54/no3/spiwak.pdf [hereinafter Why $A D C o$ ?]. See also Gerald R. Faulhaber \& Christiaan Hogendorn, The Market Structure of Broadband Communications, Unpublished Manuscript, Research Center: Public Policy and Management Department, (1999), available at http://knowledge.wharton.upenn.edu/pap ers/701.pdf.

2. Unless, of course, these five to seven firms somehow collude to artificially raise prices to allow this structure.

3. For an interesting and detailed analysis of the prospects and welfare effects of competition in communications markets, see FARID GASMI ET AL., CoST ProXY MODELS AND TELECOMMUNICATIONS POLICY 65 (2002).

4. The HHI is an accepted measure of market concentration. The index is calculated by summing the squared market shares of each firm. For example, a market consisting of three equal sized firms has an HHI of $3,333\left(=33^{2}+33^{2}+33^{2}\right)$. The numbers equivalent is simply [1/(HHV/1000)], where this ratio measures the number of hypothetical, equally-sized firms in a market (irrespective of the actual distribution of market shares).

5. FCC, INDUSTRY ANALYSIS AND TECHNOlOGY Division, WirEline COMPETITION BUREAU, TRENDS IN TELEPHONE SERVICE 9-11 (Apr. 2005), available at http://www.fec.gov 
historically by substantial price and quality competition.

Nor do few facilities-based local distribution networks imply few competitors. For example, over 1,000 firms offer long-distance services over about six nationwide long-haul networks. ${ }^{6}$ A more contemporary example is the existence of many firms, large and small, offering consumers telephone service using Voice-over-Internet-Protocol ("VoIP") technology. These "service" providers can provide meaningful benefits to consumers in both price and non-price dimensions, even though these providers did not spend billions to construct networks.

Similarly, focusing narrowly on terrestrial, local distribution networks can present a misleading picture of rivalry. Alternative technologies, including wireless and satellite platforms, clearly expand service offerings to consumers, and in some cases provide meaningful price competition to more traditional communications services, even if only for subsets of consumers. ${ }^{7}$ Wireless carriers are investing billions in $3 \mathrm{G}$ technologies (e.g., EVDO) capable of providing advanced services, including some video applications. Even if these intermodal substitutes (versus intermodal competitors) do not provide a significant constraint on market power in traditional voice and video markets (though they may), they can have the effect of shrinking the negative effects of market power by reducing the size of traditional markets. ${ }^{8}$ Minutes of long-distance telecommunications traffic have fallen by twenty-five percent over the past five years, probably due to increased use of wireless telephone services and email. ${ }^{9}$ While such substitution may not reduce prices, it clearly reduces the relevance of any

/Bureaus/Common_Carrier/Reports/FCC-State_Link/IAD/trend605.pdf [hereinafter TRENDS IN TELEPHONE SERVICE 2005].

6. Id. at 9-16.

7. Analysts suggest that roughly nine percent of households have "cut the cord," using wireless exclusively for telephone service. See David W. Barden, Banc of America Securities Report, 2Q05 TeleCOM Results Heads Up 2 (July 13, 2005). This does not imply, however, that wireless and wireline are effective economic substitutes. To be economic substitutes, there has to be some price at which both the buyer will switch back to wireline and the seller would be willing to offer the service. See, e.g., Greg Lalas, The Year of Living Wirelessly. THE BosTON GLOBE, Apr. 24, 2005, available at http://www.boston. com/business/technology/articles/2005/04/24/the_year_of_living_wirelessly/. See also Time to Deregulate Wireline Communications in Texas: Before the Texas House Comm. on Regulated Industries, 2004 Leg., 78th Sess. (2004) (remarks of Barry M. Aarons, Research Fellow, Institute for Policy Innovation), available at http://www.ipi.org/ipi/IPIPublications. nsf/0/219fe5f44f5997f186256e6e00739891?OpenDocument ("[My youngest son] who upon moving to [Butte, Montana] and renting a house decided that having cellular service was enough and having a hard wire residential local service was a waste of money. . . [T]he local phone company, Qwest, was never under consideration ....").

8. As markets shrink, the absolute size of welfare loss from market power shrinks with it, and justifying the expense of remedial action becomes more difficult as the market gets smaller.

9. TRends IN TELEPHONE SeRvice 2005, supra note 5, at 10-3. 
residual market power in the long-distance market. ${ }^{10}$

Alternatively, intermodal competitors (in contrast to intermodal substitutes), like intramodal rivals, strike directly at margins, providing substantial and direct consumer benefits in both price and nonprice dimensions. ${ }^{11}$ A government study shows, for example, that wireline (intramodal) competition in the cable television industry provides three times the price reduction as satellite competitors do (intramodal competition). Our focus in this Article is on intermodal competitors of arguably the most significant kind, that is those competitors offering very close substitutes to the traditional services (voice, video, and data) consumed by the vast majority of consumers (or the typical household).

Given the inevitability of fewness in the number of competitors of this kind, it is vital for policymakers to understand the entry decisions of firms so that the number of competitors can be maximized under the relevant demand- and supply-side constraints of the market.

First and foremost, policymakers must identify and change those policies that make it more difficult for firms to enter or to expand into related markets. Recent advances in technology have substantially expanded the potential for facilities-based entry and intermodal competition, provided regulation does not foreclose opportunities for competitive entry, and that regulators do not act in concert with incumbents to raise effective entry barriers. The value of one more entrants in a concentrated market is sizeable, so policymakers should favor entry to the greatest extent possible. To do so, policymakers must understand the entry calculus of firms and be able to apply the logic of this entry calculus to decipher how particular policies may affect entry. We provide in this Article a simple conceptual framework of entry ideally suited for the evaluation of policies that may influence the entry decisions of firms.

10. This type of substitution is perhaps best viewed as a rotation about the price axis intercept of, rather than a shift of, the demand curve. If the demand curve rotates as the number of potential customers falls, then the profit-maximizing price may not change. Nevertheless, the profits and welfare losses resulting from market power are reduced. The payphone market is a good example. While many describe mobile phones and payphones as competitors, they are better characterized as intermodal substitutes, since as mobile telephony has grown, payphone prices have risen. In essence, the owner of a mobile phone has left the payphone market.

11. The difference between intermodal substitutes and competitors is perhaps best made in the context of antitrust market definition. An intermodal competitor would be in the "antitrust" market of the traditional service (a close substitute that meaningfully affects market power), where an intermodal substitute would not. See PHOENIX CENTER FOR Advanced Legal \& Economic Public Policy Studies, Fixed-Mobile "Intermodal" Competition in Telecommunications: Fact or Fiction? PhOENIX CENTER POLICY BulletIN No. 10, (Mar. 31, 2004), available at http://www.phoenix-center.org/PolicyBulletin/PCPB1 0Final.pdf (applying this logic to wireless/wireline substitution). 
To flush these important points out in further detail, this Article is outlined as follows: Part II first establishes the fact that local telecoms markets will be characterized by only a "few" facilities-based firms. This Part draws on the economic literature on entry to show that given the huge sunk costs required for entry, the equilibrium number of terrestrial firms for the local market will be highly concentrated. Part III goes on to present a simple and intuitive economic model of entry accessible to the layperson, which illustrates the concept of an equilibrium industry structure. In this Part, we describe the primary determinants of competitive entry and present simple numerical examples to facilitate comprehension. Part IV includes four applications of the logic of our entry model to real-world policy issues.

For example, there has always been great talk about "convergence," but true convergence (i.e., one that actually affects the underlying market structure) is not the offering of a "bundle" of several products into a single service offering, but is, in fact, a technological spillover that reduces entry costs so that existing firms find it profitable to extend their networks into related markets, a decision that would not be profitable without the spillover. As such, "convergence" does not generally mean that busloads of new firms can now enter the market-it means only those firms with assets in a related market that have been affected by the spillover can afford to enter.

Similarly, if policymakers artificially restrict or impede access to various ancillary product markets, then firms may not expand into related markets or upgrade their existing networks (e.g., copper to fiber) to facilitate the technological "convergence" discussed previously. If network modernization is to occur, then regulatory entry barriers that exist in any market that the network is capable of serving must be eliminated to the greatest extent possible.

The same can also be said about arguments for so-called "regulatory symmetry," such as franchise and build-out requirements on new terrestrial multichannel video programming distributors ("MVPD"), because such requirements, in fact, treat sunk costs incurred by the new entrant and the incumbent in a very asymmetrical way. As we show, incumbents can incur more sunk costs than entrants because their profits are higher. In fact, many cable systems were constructed during the era of exclusive franchising, so an incumbent firm incurred these costs at a time when it was guaranteed a monopoly over cable services in the area. A firm offered a monopoly would readily propose or agree to a higher entry cost than it otherwise would have agreed to in a competitive environment, particularly if policy requires future entrants to match the sunk entry costs of the incumbent.

Finally, but perhaps most importantly, after all of these hurdles are overcome, the level and degree of entry can tell us much about the potential 
for collusion. As we show, it can be easy to confuse collusion with intense price competition, and this confusion arises primarily from a strict adherence to the traditional view that the intensity of price competition rises with the number of firms. ${ }^{12}$ Once the effects of sunk costs are incorporated into the model of competition, however, such a simple notion of competition no longer tells the complete story because the easiest time for firms to collude is before they enter one another's markets. As such, if we observe reciprocal entry, then this is solid evidence that collusion is not occurring. Indeed, as we continue to witness cable operators moving into the telephone business and the telephone companies moving aggressively into the video business, this simple observation alone is strong evidence that collusion is not present.

\section{INDUSTRY CONCENTRATION IN COMMUNICATIONS MARKETS}

The construction of a local communications network-whether used for voice, video, data, or some combination thereof-requires enormous capital expenditures. These expenditures are fixed costs and, consequently, firms in these markets have considerable economies of scale (i.e., average costs fall as output increases). ${ }^{13}$ The presence of these significant scale economies results in highly-concentrated market structures, since larger firms operate at a sizeable cost advantage over smaller firms.

This situation is exacerbated by the fact that in local communications markets, a good deal of these fixed costs are also "sunk." A sunk cost is a cost that, once incurred, cannot readily be recovered (it cannot be sold in an aftermarket). A communications plant, once installed, has no other use and, thus, cannot readily be sold in an aftermarket for alternative uses. In addition to scale economies, fixed costs that are sunk raise the risk of entry, since investments that are sunk have virtually no value if the business fails. $^{14}$

The effects of fixed (scale economies) and sunk costs on equilibrium industry structure are well known. In fact, there are few theoretical concepts in economics with more empirical support than the relationship of sunk costs and scale economies to industry structure. ${ }^{15}$

12. In other words, the effect on price by the entry of an additional firm can vary across markets and, the larger the effect, the more intense is price competition.

13. Scale economies are a characteristic of the firm, not of a particular technology used by the firm. "Density economies" is a term often used to describe the cost/output relationship for a particular technology or asset used by a firm. The presence of either or both can lead to higher industry concentration.

14. In fact, a large portion of the capital expense of constructing a communications plant is installation costs, and expended installation labor clearly has no value in an aftermarket.

15. See, e.g., Timothy F. Bresnahan et al., Do Entry Conditions Vary Across Markets?, 
From a theoretical (and empirical) perspective, Sutton (1995) provides an excellent treatment of the relationship of sunk costs to market structure. $^{16}$ What his theoretical analysis shows is that, under certain conditions, the equilibrium number of firms in a market is equal to (the integer part of $)^{17}$

$$
N^{*}=\sqrt{S / E} \quad(\text { Equation 1) }
$$

where $N^{*}$ is the equilibrium number of firms, $S$ is the market size measured as the lifetime expenditures of consumers, and $E$ is the sunk entry costs. ${ }^{18}$ The equilibrium number of firms in a market is obtained when no firm has either the incentive to enter or to exit the market. Equation (1) indicates that if market size is $\$ 10$ billion (measured as the present value of the flow of gross profits over the life of the investment), and entry costs are $\$ 2$ billion, then the equilibrium number of firms is $N^{*}=2 .^{19}$ If entry costs

in 3 BROOKINGS PAPERS ON ECON. ACTIVITY 833-81 (Martin Neil Baily \& Clifford Winston eds., 1987); Mita Bhattacharya, Industrial Concentration and Competition in Malaysian Manufacturing, 34 APPLIED ECON. 2127 (2002); E. Woodrow Eckard, Jr., Plant-level Scale Economies and Industrial Concentration, 34 Q. REV. OF ECON. AND FIN. 173 (1994); P. A. Geroski et al., The Dynamics of Market Structure, 5 INT'L J. OF INDUS. ORG. 93 (1987); Douglas F. Greer, The Causes of Concentration in the US Brewing Industry, 21 Q. REV. OF ECON. AND BUS. 87 (1981); Frederic Jenny \& Andre-Paul Weber, The Determinants of Concentration Trends in the French Manufacturing Sector, 26 J. OF INDUS. ECON. 193 (1978); Ioannis N. Kessides, Market Concentration, Contestability, and Sunk Costs, 72 REV. of ECON. AND STATS. 614 (1990); Ionnis N. Kessides, Advertising, Sunk Costs, and Barriers to Entry, 68 REv. OF ECON. AND STATS. 84 (1986) [hereinafter Advertising. Sunk Costs, and Barriers]; David Levy, Specifying the Dynamics of Industry Concentration, $34 \mathrm{~J}$. OF INDUS. ECON. 55 (1985); Walter J. Mayer \& William F. Chappell, Determinants of Entry and Exit: An Application of the Compounded Bivariate Poisson Distribution to U.S. Industries, 19721977, 58 S. EcoN. J. 770 (1992); Catherine J. Morrison Paul, Cost Economies: A Driving Force for Consolidation and Concentration?, 70 S. ECON. J. 110 (2003).

16. See John SUTtON, SUNK Costs AND MARKET STRUCTURE ch. 2 (1991).

17. The assumptions of the model include Cournot competition in quantities, an isoelastic demand curve (that is, the demand elasticity is constant and equal to -1), constant costs, and symmetric firms. The game is a two-stage game, and the equilibrium is a Nash Equilibrium. See id.

18. In the telecommunications industry, company filings before the Securities and Exchange Commission show a variety in the ratios of "Revenues" to "Property Plant and Equipment." A low ratio indicates the market in which one would expect a higher level of concentration. Ranked from lowest to highest, the ratios are as follows: (1) local exchange 0.92 (BellSouth); (2) cable television 1.08 (Comcast); (3) mobile telephony 1.35 (Nextel); (4) long-distance networks 2.65 (AT\&T); (5) UNE-P providers 7.16 (Talk-America); and (6) VolP retailers 64.8 (GlobeTel). The number of firms in each "market" is inversely correlated with these ratios. Of course, a more sophisticated analysis of capital stock to entry is required for a more compelling relationship of fixed/sunk costs to industry structure. See supra note 15 for a list of studies on this topic.

19. The calculation is $\operatorname{INT}(10 / 2)^{-2}=\operatorname{INT}(2.24)=2$. 
rise to $\$ 3$ billion, however, then the equilibrium is monopoly, or $N^{*}=1^{20}$ Equation (1) reveals that the equilibrium number of firms rises as the market gets larger ( $S$ gets bigger, other things constant), but falls as sunk costs rise ( $E$ gets bigger, other things constant). ${ }^{21}$

Perhaps the most important point for modern communications policy obtained from Equation (1) is that the sustainable number of firms in a market depends on the economic characteristics of the market, and not the desired, arbitrarily selected number of firms by some group of policymakers, trade group presidents, legislators, or other types of social reformers (no matter how well-intentioned). While public policy cannot choose the long-run sustainable number of firms in a market, policymakers can take steps to affect the economic character of markets and consequently influence the equilibrium number of firms. One clear example is investment tax credits, which directly lower sunk costs of entry by lowering taxes on such investment. ${ }^{22}$ In addition, since the sustainable number of firms in a market is a function of the size of that market, public policy can help expand that market, say by removing international trade barriers. $^{23}$

It is important to recognize that a number of U.S. industriesincluding several that nearly all would regard as competitive-are relatively concentrated. The household refrigerator and freezer business has an $\mathrm{HHI}$ index of over 2000, silverware manufacturing an $\mathrm{HHI}$ of nearly 2800 , and glass container manufacturing has an $\mathrm{HHI}$ of $3000 .^{24}$ The construction of large jetliners presently has only two competitors-Boeing and Airbus. $^{25}$ Indeed, while it is common to associate high concentration with poor market performance, the empirical evidence does not consistently support this common view. High industry concentration does not $a$ fortiori mean that the interests of consumers are poorly served.

20. The calculation is $\mathbb{I N T}(10 / 3)^{-2}=\mathbb{I N T}(1.83)=1$.

21. While Equation (1) does not explicitly point to scale economies, the presence of scale economies is implicit. The limit on the number of firms is based on the inability of additional firms to achieve sufficient scale to serve the market profitably. For an extension of Equation (1) to a case of generalized conjectural variations, see Duvall \& Ford, supra note 1 .

22. See, e.g., Anastassios Gentzoglanis, Sunk Costs, Innovation, and Spillover Effects in $R \& D$-Intensive Industries, $10 \mathrm{~J}$. OF APPLIED Bus. RES. 1 (1994).

23. The ability of international trade to expand markets and thereby reduce industry concentration is shown empirically in William F. Chappell \& Bruce Yandle, An Entry Model of Import Penetration, 19 ATLANTIC ECON. J. 22 (1991).

24. ECON. AND Statistics Admin., U.S. Census Bureau, U.S. Dep'T. of Commerce, CONCENTRATION RATIOS IN MANUfACTURING: 1997 ECONOMIC CENSUS 16 (2001).

25. Thomas Boeder \& Gary Dorman, The Boeing/McDonnell Douglas Merger: The Economics: Antitrust Law and Politics of the Aerospace Industry, 45 ANTITRUST BULLETIN $119(2000)$. 
Competition in concentrated markets has been shown to provide good performance in many industries. ${ }^{26}$

While law and public policy can make markets more conducive to entry, they can also result in even fewer firms. For example, cable franchise contracts result in more concentrated markets for video programming distribution by raising entry costs. According to the Federal Communications Commission, "The local franchise process is, perhaps, the most important policy-relevant barrier to competitive entry in local cable markets. "27 It should come as no surprise that the only relatively successful MVPD entrant to date is Direct Broadcast Satellite ("DBS"), which does not need a local franchise to operate. Until 1996, public policy in many states made entry into the local telephone business illegal, which certainly constituted a significant barrier to entry. ${ }^{28}$

Sometimes policymakers are unaware that their actions have an impact on market entry and industry structure. ${ }^{29}$ At other times, policymakers take very explicit steps directed at affecting market structure.

26. See, e.g., Michael Salinger et al., The Concentration-Margins Relationship Reconsidered, in BROOKINGS PAPERS ON ECON. ACTIVITY 287-335 (Martin Neil Baily \& Clifford Winston eds., 1990); Gary Whalen, The Determinants and Performance Effects of Rivalry in Local Banking Markets, 31 Q. J. OF Bus. AND ECON. 38 (1992) ("[C]oncentration affected neither rivalry nor profitability in the expected manner."); Myron B. Slovin et al., Deregulation, Contestability, and Airline Acquisitions, 30 J. OF FIN. ECON. 231 (1991) ("Changes in concentration after deregulation have no positive effect on carrier returns."); John R. Schroeter, Estimating the Degree of Market Power in the Beef Packing Industry, 70 REV. OF ECON. AND STATS. 158 (1988); Stephen A. Rhoades, Market Share as a Source of Market Power: Implications and Some Evidence, 37 J. OF ECON. AND Bus. 343, 343 (1985) ("[M]arket share per se is a source of high profits, regardless of the level of concentration and after controlling for firm size."); Roger L. Beck \& Sheila Mozejko, Concentration and Price/Cost Margins Across Time in Canada, 9 Revue CanadienNe Des ScIENCES DE L'ADMINISTRATION 40 (1992) ("[W] hen [a shift occurs] from a single-point-in-time to a sequential-points-in-time approach, there is no longer a consistent relationship between changes in concentration and changes in profit margins ....").

27. Implementation of Section 19 of the Cable Television Consumer Protection and Competition Act of 1992, First Report, 9 F.C.C.R. 7442, app. H, para. 43 (1994) [hereinafter First FCC Cable Competition Report]. See also Richard A. Posner, The Appropriate Scope of Regulation in the Cable Television Industry, 3 BELL J. OF ECON. \& MGMT. SCI. 98 (1972).

28. Such laws were pre-empted by Section 253 of the Telecommunications Act of 1996, Pub. L. No. 104-104, 110 Stat. 56 (codified at 47 U.S.C. § 253(a) (2000)). See Pub. Util. Comm'n of Tex., Memorandum Opinion and Order, 13 F.C.C.R. 3460, para. 4 (1997).

29. Another example of a policy that increased concentration is legal restrictions on advertising by cigarette companies. These restrictions limited the ability of entrants to inform consumers about their products. See, e.g., E. Woodrow Eckard, Jr., Competition and the Cigarette TV Advertising Ban, 29 ECON. INQUIRY 119, 119 (1991). Advertising has two countervailing effects on industry structure. It raises the sunk costs of entry, thereby raising concentration. But, advertising is required for entry, since consumers must be informed about new products. See generally Advertising, Sunk Costs, and Barriers, supra note 15 (an empirical test of these two countervailing effects of sunk advertising expenditures). 
Take, for example, the wireless PCS auctions. In the early 1990s, the FCC auctioned off hundreds of geographically-divided licenses for PCS spectrum based upon an assumption that making five licenses available over multiple geographies would result in a more competitive outcome than alternatives proposed. The FCC could not have known then whether or not five licensees in various overlapping geographies would be "too many" or "too few." It now appears that the FCC acted conservatively and issued far too many licenses for the ultimate wireless industry structure, which seems to be trending toward four or so (more or less) national networks (SprintNextel, Verizon Wireless, AT\&T/Cingular, and T-Mobile) with additional regional, fringe competitors (like U.S. Cellular and ALLTEL) in certain areas. Today, we should not be surprised to see wireless industry mergers occur when the government has initially (and artificially) divvied up crucial raw materials among more firms than the industry appears to be able to profitably sustain. ${ }^{30}$

As we discuss more fully below, in light of the fact that communications markets will be-by their very nature-concentrated, policymakers should do what they can to make all communications markets more conducive to facilities-based entry. Indeed, as technology is transforming traditional single use networks (i.e., telephone or cable networks) into multi-use networks (i.e., advanced broadband networks that can provide telephone, video, and data), competition between a few firms and the elimination of monopoly in the communications and video industries is now possible - but only if new and existing firms are not artificially hamstrung by regulations that limit their ability to utilize their networks to compete over all particular parts of a bundle of voice, video, and data services. As a result, instead of focusing on how many firms are present in a market, policymakers should appropriately focus on what policies will facilitate entry by firms.

\section{AN ENTRY-ORIENTED MODEL OF INDUSTRY STRUCTURE FOR POLICY ANALYSIS}

Since domestic policymakers have chosen to rely on facilities-based entry in communications markets, policymakers focused on consumer welfare need to think in an analytical way about how this competition will develop. The most important aspect of network platform facilities-based

30. A similar wave of consolidation occurred in the radio industry after Congress significantly altered FCC rules that artificially limited the number of radio stations one firm could own. See generally Robert B. Ekelund, George S. Ford \& Thomas M. Koutsky, Market Power in Radio Markets: An Empirical Analysis of Local and National Concentration, 43 J.L. \& ECON. 157 (2000) (empirically demonstrating that the FCC's own rules created maximum fragmentation in the industry by nearly forbidding multi-station owners). 
competition for consumers is and will be the nature, quality, quantity, and diversity of communications services available over those competing network platforms. And, since we are in an environment in which traditional single-use networks are being transformed into advanced, multiple-use platforms competition, this transformation-to a large extent-will hinge on how those network platforms will enter one another's markets and how public policy will affect the mobility of existing networks into new lines of business.

In this Part, we present a simple and intuitive framework for analyzing the factors that influence entry. We then utilize specific examples in order to show in more detail how policies affect the equilibrium number of firms and the behavior of those firms. The numerical examples provided are not intended to reflect precisely any particular industry and are not drawn from empirical analysis, but are presented merely to illustrate the concepts embodied in the conceptual framework.

At the core of the economic framework is the obvious notion that firms will enter a market only if it is profitable to do so, and firms will exit a market if they find it unprofitable. As a result, any model of entry must focus upon the profit function of the firm. Our framework is based on this very simple logic and is consistent with earlier work on entry such as Salop (1979), Van Witteloostuijn (1993), Sutton (1995), Hazlett \& Ford (2001), Ford \& Duvall (2001), and a plethora of other academic and policy papers. $^{31}$

Our discussion can be made more concise by the introduction of some simple notation. Let $d$ be the flow of gross profits over the life of some venture, and let $e$ be the sunk setup costs (e.g., entry costs) to enter the market. We use the variable $d$ to indicate profits since many entry models evaluate entry in the context of duopolistic competition (hence " $d$ "). The flow of profits should be thought of as the sum of the difference between revenues and variable costs (in present value form). Entry costs, in this simple framework, are all upfront costs incurred immediately upon entry. These entry costs are fixed and sunk. The profitability of entry is determined by the difference between gross profits $(d)$ and entry costs $(e)$. Since firms only enter if profits are positive (or non-negative), we have entry when $d-e \geq 0$. If $d-e<0$, then the firm stays out of the market (i.e., does not enter). Thus, firms will enter as long as it is profitable to do so, and when entry stops, the existing number of firms will be the equilibrium

31. See Steven C. Salop, Strategic Entry Deterrence, 69 AM. ECON. REv. 335 (1979); Arjen Van Witteloostuijn, Multimarket Competition and Business Strategy, 8 REv. INDUS. ORG. 83 (1993); SUTTON, supra note 16; Thomas W. Hazlett \& George S. Ford, The Fallacy of Regulatory Symmetry: An Economic Analysis of the 'Level Playing Field' in Cable TV Franchising Statutes, 3 Bus. \& Pol. 21 (2001); Duvall \& Ford, supra note 1. 
number of firms $\left(N^{*}\right)$. All firms, from lemonade stands to fiber network operators go through this calculus in deciding whether to enter any new market.

The simple entry model, applied in a generic setting, is illustrated in Table 1. In the first column, there is a count of the number of firms in the market $(N)$. In the second and third columns, profit $(d)$ and entry costs $(e)$ are listed. Profits are assumed to fall with the number of firms, a point we discuss in detail in the next section. ${ }^{32}$ Entry costs are constant at $\$ 15^{33}$ Working through the table, it should be clear that the equilibrium number of firms in this example is 3. Firm one makes a large profit of $\$ 85$. Upon the entry of firm two, profits fall to $\$ 40$ per firm, but this profit is more than sufficient to cover the entry costs of $\$ 15$. Likewise, the per-firm profits of $\$ 20$ at three firms are larger than entry costs, so three firms enter. But when the fourth firm enters, profits fall below entry costs $(\$ 12<\$ 15)$, so the fourth firm stays out. Thus, we have equilibrium of three firms-no existing firm has an incentive to exit, and no new firm has the incentive to enter. Note that all firms earn positive economic profits in equilibrium (\$5), but there is no threat of entry. ${ }^{\text {f4 }}$

\begin{tabular}{llll}
\hline \multicolumn{4}{l}{ Table } \\
\hline $\mathrm{N}$ & The Equilibrium Number of Firms \\
\hline 1 & $\mathrm{~d}$ & $\mathrm{E}$ & $d-e$ \\
\hline 2 & 100 & 15 & 85 \\
\hline 3 & 40 & 15 & 25 \\
\hline 4 & 20 & 15 & 5 \\
5 & 12 & 15 & -3 \\
6 & 8 & 15 & -7 \\
7 & 5 & 15 & -10 \\
\hline
\end{tabular}

32. Profits are for illustrative purposes only and do not represent expected or actual price declines in any particular market.

33. Note that industry profits at two firms are $\$ 80$, versus $\$ 100$ at monopoly. In the absence of perfect collusion, industry profits will decline as the number of firms rises. Even if collusion occurs and industry profits remain at $\$ 100$, then per-firm profits will decline (i.e., $\$ 100 / N$ ).

34. As entry costs fall to zero, then the economic profits of existing firms fall to zero. Thus, entry costs represent a barrier to entry in the traditional sense of allowing positive price-cost margins. See, e.g., JoE S. BAIN, BARRIERS to NEW COMPETITION 190-91 (1956). What we have leamed from this analysis (summarized in Table 1) is how incumbent firms can sometimes be perceived as having an exaggerated perception of the degree of competition in a market. In markets with large capital expenditures, the addition of one additional firm may change the incumbent's situation from one of persistent profits to persistent losses. Thus, one's perception of the effects of one more firm depends on the effects of one more firm. With few firms and sunk costs, the effect of one more firm is nearly always sizeable. 
This simple condition on entry (i.e., $d-e$ positive or negative), illustrated numerically in Table 1, is the core of our economic framework, and all economic models of entry. While we can and do delve into the finer properties of $d$ and $e$, these two variables encapsulate the most important components of the entry decision and the nature of the equilibrium structure. Put simply, a prospective entrant asks, "What is it worth for me to enter?" and "What does it cost me to enter?" If the benefits exceed the costs, then entry occurs. This thought process lies at the core of nearly all of economic science. For policymakers, the answer is simple and intuitive-if you want there to be more entry, figure out how to make entry more profitable. In particular, investigate and implement rules that increase gross profits $(d)$, reduce entry costs $(e)$, or, better yet, both (without harming consumers, of course).

\section{A. Factors Determining Profits}

As just described, it is the relationship between expected profits (d) and entry costs $(e)$ that drives the entry decisions. Per-firm profits will fall as the number of firms increases, even with perfect collusion (as the monopoly profit is divided among a larger numbers of firms). Aside from the number of firms, we view profits as being driven by four factors: (1) the size of the market; (2) the intensity of price competition; (3) the extent of product differentiation; and (4) the degree to which two rival networks overlap in their markets served. The effects of each factor are summarized in Table 2, and the factors are described in more detail in the following Parts.

\begin{tabular}{lll}
\hline \multicolumn{3}{l}{ Table 2. Factors Determining Profits } \\
\hline Factor & $\begin{array}{l}\text { Relationship } \\
\text { to } d\end{array}$ & $\begin{array}{l}\text { Effect } \\
\text { on } N^{*}\end{array}$ \\
\hline $\begin{array}{l}\text { Larger Market Size } \\
\begin{array}{l}\text { More Intense Price } \\
\text { Competition }\end{array}\end{array}$ & + & More firms \\
$\begin{array}{l}\text { More Product Differentiation } \\
\text { More Overlap of Rival } \\
\text { Networks }\end{array}$ & - & Fewer firms \\
\hline
\end{tabular}




\section{Market Size and Entry}

All other things constant, an increase in market size will increase profits and, therefore, the number of firms that can profitably serve that market. ${ }^{35}$ The easiest way to think about how markets can increase in size is in international trade. For example, the removal of a tariff on a product increases the number of profitable sales for that product and invariably increases the size of the market and profits. ${ }^{36}$ As we discuss later, market size is not necessarily the size of consumers' expenditures on a single product or service-it can also involve the potential for sales of additional or new services over the same infrastructure. A law that prohibits stores of a certain size from selling groceries (as anti-Wal-Mart advocates often suggest) limits the size of the market that Wal-Mart can address and therefore limits profits and makes Wal-Mart entry less likely (the intended effect, of course). Like large stores, communications networks can often provide and sell multiple services, so market size can be approximated as total expenditures on the full array of services available over the network. Precluding the sale of particular services that a network is capable of providing obviously reduces market size and, therefore, reduces entry.

\begin{tabular}{|c|c|c|c|c|c|}
\hline & & Exa & $: N^{*}=3$ & Exal & $: N^{*}=4$ \\
\hline $\mathrm{n}$ & e & $\mathrm{d}$ & $d-e$ & e & $\mathrm{d}-\mathrm{e}$ \\
\hline 1 & 15 & 100 & 85 & 150 & 135 \\
\hline 2 & 15 & 40 & 25 & 60 & 45 \\
\hline 3 & 15 & 20 & 5 & 30 & 15 \\
\hline 4 & 15 & 12 & -3 & 18 & 3 \\
\hline 5 & 15 & 8 & -7 & 12 & -3 \\
\hline 6 & 15 & 5 & -10 & 8 & -7 \\
\hline 7 & 15 & 4 & -11 & 6 & -9 \\
\hline
\end{tabular}

We can extend our simple numerical example in Table 1 to illustrate the effect of market size. Our discussion indicates that larger markets increase profits and, consequently, may increase the number of firms in equilibrium. Example 1 in Table 3 is simply a replication of our initial

35. This point is obvious. For any given price-cost margin $(m)$, profits are $m(q)$, where $q$ is firm output. As $q$ rises and $m$ remains constant, profits rise. Empirical evidence on relationship of industry concentration to market size is provided by S. Kellner \& G. Frank Mathewson, Entry, Size Distribution, Scale, and Scope Economies in the Life Insurance Industry, 56 J. BuS. 25 (1983); Malcolm B. Coate, The Dynamics of Price-Cost Margins in Concentrated Industries, 21 APPLIED ECON. 261 (1989); Bhattacharya, supra note 15; Chappell \& Yandle, supra note 23.

36. See id. at 22 . 
example with an equilibrium number of firms $N^{*}=3$. In Example 2, however, we increase the size of the market by 50 percent-for instance, an import tariff abroad has been eliminated. ${ }^{37}$ Now, monopoly profits are $\$ 150$, up $\$ 50$ from Example 1 . With entry costs constant (at $\$ 15$ ), this larger market is capable of sustaining four firms $\left(N^{*}=4\right)$, since each firm is profitable at four firms $(d-e=\$ 3)$, but none is profitable at five firms $(d-e=-\$ 3)$. Clearly, larger markets, per dollar of sunk costs, result in a larger number of equilibrium firms. ${ }^{38}$

\section{The Intensity of Price Competition}

Profits are also affected by the intensity of price competition. If firms compete aggressively, then profits will fall sharply when new firms enter. Weak price competition, alternatively, allows profits to fall more slowly as additional firms enter. The relationship of price/profit reductions and additional firms has important implications for industry structure.

The model of small numbers competition that is the basis of most views on the issue is Cournot competition in quantities. ${ }^{39}$ With this form of competition, market price falls and quantity rises to the perfectly competitive levels as the number of firms increases. In its most basic form, for example, the market quantity is $\left[N /(N+1) \cdot Q_{C}\right]$, where $N$ is the number of firms and $Q_{C}$ is the quantity sold with perfect competition. As $N$ increases, the Cournot quantity gets closer to the perfectly competitive quantity. ${ }^{40}$ Only with perfect collusion (which is practically unobtainable) would gross profits remain at the monopoly level as the number of firms increases. At the other extreme, we may have very intense price competition (i.e., Bertrand competition in prices) so the perfectly

37. Profits are for illustrative purposes only and do not represent expected or actual price declines in any particular market. The larger market is assumed to be 50 percent larger than the initial case.

38. Of course, the increase in market size must be large enough to alter the entry decision of the marginal firm.

39. This relationship is certainly true of Coumot competition in quantities, which typically results in a smooth movement from monopoly to perfectly competitive prices as the number of rivals increases. In the Cournot model, rival firms choose the quantity they wish to offer for sale. Each firm maximizes profit on the assumption that the quantity produced by its rivals is not affected by its own output decisions. With Bertrand competition in prices and homogenous products, the duopoly price is equal to the perfectly competitive price. With heterogeneous products, the Bertrand equilibrium price falls toward the perfectly competitive price as the number of firms enter. Kreps and Scheinkman show that when firms must first choose capacity plant size, the equilibrium of Bertrand competition in prices is identical to that of the simple Cournot model. See generally David Kreps \& Jose A. Scheinkman, Quantity Precommitment and Bertrand Competition Yield Cournot Outcomes, 14 BELL J. ECON. 326 (1983).

40. A monopolist sells one-half the competitive output $[1 /(1+1)=0.5]$. At five firms, the industry output is 83 percent $(=5 / 6)$ of the perfectly competitive output. 
competitive price is obtained with only two firms. In this case, the addition of firms after the second firm will have no effect on prices or profits.

These widely disparate competitive interactions are not only theoretical. Empirical and experimental research has shown that there is substantial variation in the relationship between the number of firms (or industry concentration) and prices/profits across industries and over time.

Experimental research is particularly interesting on this point. Fouraker and Siegel (1963) evaluated the competitive behavior of sixteen pairs of "student duopolists." I1 In seven of sixteen games, the Cournot equilibrium was observed. Other outcomes included five Bertrand (perfect competition) outcomes, three collusive outcomes, and one outcome between collusion and Cournot. The average outcome was Cournot, but there were significant departures from Cournot behavior. These experiments illustrate the variety of outcomes possible with small number competition. Interestingly, when the experiment was extended to three players, the Bertrand outcome was the most common. ${ }^{42}$ Holt (1985) and Plott (1982) also find support for the Cournot outcome in experiments. ${ }^{43}$

There are many empirical studies showing a positive relationship between concentration and prices/profits; but, there also exists a large literature showing no link between the two. Econometric research finds support for the Cournot outcome, as well as more and less competitive outcomes. Iwata (1974) could not reject the Cournot outcome in the Japanese glass industry, and Brander \& Zhang (1990 and 1993) find evidence of Cournot outcomes in the U.S. airline industry. ${ }^{44}$ Haskel \& Martin (1994) find support for Cournot over Bertrand behavior when firms face capacity constraints. ${ }^{45}$ But, Berg \& Kim (1994) reject Cournot behavior in the Norwegian banking industry, and Ford (2000) presents evidence that the international message telephone industry is more competitive than Cournot. ${ }^{46}$ Karp \& Perloff (1989) show that the

41. LaWrenCe E. Fouraker \& Sidney Siegel, Bargaining Behavior 140-42 (1963).

42. Id. at $139-40$.

43. See Charles A. Holt, An Experimental Test of the Consistent-Conjectures Hypothesis, 75 AM. ECON. REV. 314 (1985); Charles R. Plott, Industrial Organization Theory and Experimental Economics, 20 J. ECON. LITERATURE 1485 (1982).

44. See Gyoichi Iwata, Measurement of Conjectural Variations in Oligopoly, 42 ECONOMETRICA 947 (1974); James A. Brander \& Anming Zhang, Market Conduct in the Airline Industry: An Empirical Investigation, 21 RAND J. ECON. 567, 581 (1990); James A. Brander \& Anming Zhang, Dynamic Oligopoly Behaviour in the Airline Industry, 11 INT'L J. INDUS. ORG. 407, 433 (1993).

45. See Jonathan Haskel \& Christopher Martin, Capacity and Competition: Empirical Evidence on UK Panel Data, 42 J. INDUS. ECON. 23, 37-38 (1994).

46. See Sigbjern A. Berg \& Moshe Kim, Oligopolistic Interdependence and the Structure of Production in Banking: An Empirical Evaluation, 26 J. MONEY, CREDIT \& BANKING 309, 320-21 (1994); George S. Ford, Flow-Through and Competition in the 
oligopolistic rice market is closer to the competitive than the collusive outcome. ${ }^{47}$ Without question, the empirical economics literature supports neither a simple nor consistent relationship between industry concentration and prices or profits. Competition among small numbers of firms can produce a variety of outcomes, and it is inappropriate to assume blindly that high concentration is bad for consumers.

We know that the intensity of price competition can vary across industries, and it can produce a somewhat paradoxical result. That is, industries with intense price competition are often highly concentrated (such as soft drinks, batteries, and soup). ${ }^{48}$

This is a less than obvious point, so an illustration (Table 4) will be helpful. In all our examples thus far, adding firms reduces gross profits. However, let us assume that the market we are considering is one in which the firms necessarily must compete on price. ${ }^{49}$ The presence of price competition allows for variations in the reduction in profits per added firm. We present three examples. In all three, entry costs are $\$ 15$ and market size is constant, and the maximum gross (e.g., monopoly) profit is $\$ 100$.

International Message Telephone Service Market, PHOENIX CENTER POLICY PAPER No. 7, at 10 (Sept. 2000), available at http://www.phoenix-center.org/pcpp/PCPPP7Final.pdf.

47. Larry S. Karp \& Jeffrey M. Perloff, Dynamic Oligopoly in the Rice Export Market, 71 REV. ECON. \& STATISTICS 462 (1989).

48. For empirical evidence on the relationship of industry structure to the intensity of price competition, see Steven T. Berry, Estimation of a Model of Entry in the Airline Industry, 60 ECONOMETRICA 889, 914 (1992).

49. There is anecdotal evidence that the "residential broadband" market may be such a market. Market observers have recently noted that where robust broadband competition is present, like in Japan and some locations in Europe, price for local bandwidth drops sharply. There is anecdotal evidence that the "residential broadband" market may be such a market in which price competition plays an important role. One market observer has noted that there is a "huge increase in demand when [monthly] prices go to \$15-\$20 (Italy, France, Japan, adjusted for included phone calls) ...." Dave Burstein, Huffing and Puffing, DSL PRIME, June 8, 2005, http://www.dslprime.com/News_Articles/2005\%20news_articles.htm. 


\begin{tabular}{ll|ll|ll|ll}
\hline \multicolumn{2}{l|}{ Table 4. Price Competition and $N^{*}$} \\
\hline
\end{tabular}

Example 1 is described as "Less Intense Competition," since gross industry profits do not fall with the increasing number of firms as rapidly as they do in Example 2, "Intense Competition." ${ }^{, 50}$ Example 1 is the same as the initial example (Table 1), and the equilibrium number of firms is $N^{*}=3$. In Example 2 where competition is more intense (and profits are therefore lower), the equilibrium number of firms falls to $N^{*}=2$, since a third entrant has an expected net profit of $-\$ 3$. If firms compete aggressively on price, therefore, then the number of firms in equilibrium will be smaller than if firms are more accommodating to their rivals. Note that we have not assumed any collusion between the firms in any of these models - the fact that $N^{*}$ is lower where intense price competition is present is a symptom of intense competition and not necessarily a harbinger or evidence of collusion. ${ }^{51}$

In Example 3 in Table 4, we demonstrate how "Perfect Collusion" impacts $N^{*}$. In this example, industry profits remain at the monopoly level

50. Note that industry profits at two firms are $\$ 80$, versus $\$ 100$ at monopoly. In the absence of perfect collusion, industry profits will decline as the number of firms increases. Even if collusion occurs and industry profits remain at $\$ 100$, then per-firm profits will decline (i.e., $\$ 100 / N$ ).

51. It is often difficult to distinguish between cooperative and noncooperative behavior. For example, price leadership is often viewed as cooperative behavior, but if there is some legitimate reason for prices to rise (a cost shock, for example), it is likely that one firm will be the first to do so and then the others will follow. The behavior in this latter case is consistent with noncooperative behavior, though it may be difficult in practice to distinguish it from cooperative price leadership. Phlips provides an excellent and policy-oriented overview of this issue. Louis Phlips, Competition Policy: A GAMe-Theoretic PerspeCtive 106-23 (1995). 
(\$100) regardless of the number of firms, with each firm taking an equal share of the profits. Interestingly, given this perfect collusion, the equilibrium number of firms rises to $N^{*}=6$.

The examples in Table 4 present an interesting paradox and a challenge for policymakers. Normally, we think of price competition as becoming more intense as the number of firms rises. Yet Table 4 shows that this is not necessarily the case. As a result, policymakers must separate their assumptions about the effects on prices (or profits) from the number of firms in a market and the way in which firms interact.

An even more important lesson from the examples in Table 4 is that $a$ highly concentrated equilibrium may be the result of intense price competition rather than an indication of a lack thereof. Consider, for example, how we would view the competitiveness of the three markets in Table 4 if we adhered to the traditional view that price competition increases as the number of firms rises (the Cournot assumption). In the traditional view, we would conclude that the collusive outcome (Example $3, N^{*}=6$ ) is the most competitive, and that the most competitive outcome (Example 2, $N^{*}=2$ ) is the least competitive. The confusion arises due to the presence of fixed and sunk costs. ${ }^{52}$ Thus, the risk of such confusion is considerable in communications markets where sunk costs are significant.

The examples in Table 4 also show a potential danger for policymakers. If a policymaker has the sole goal to increase the number of firms in a market, then that policymaker would be advised to adopt policies that facilitate collusion. For some real-world examples, consider the Common Agricultural Policy of the European Union and the Northeast Dairy Compact in New England, both of which impose price and production controls with the purpose of maximizing the number of farmers and dairies in the market. By raising the price of oil, a commodity for which price competition is strong, the OPEC cartel has the effect of increasing the number of countries that can profitably produce and export oil. Consumers are not better off simply because there are more farmers, more dairies, or more oil-producing nations-indeed, they pay higher prices as a result.

Put simply, a few number of firms in a market does not necessarily mean that those few firms will not compete aggressively-indeed, there may be few firms simply because of the presence of aggressive competition. Thus, a review of competition in concentrated industry structures will likely require a more sophisticated and subtle analysis.

52. If fixed and sunk costs are small, the number of firms is likely to be very large (absent Bertrand competition in prices), so that "collusion confusion" is likely to be minimal. 


\section{Degree of Product Differentiation}

Profits are also affected by the ability of firms to differentiate their product from their competitors', called product differentiation. The more alike their products, the more a consumer's purchase decision will be based purely on price. As a result, competition among firms selling homogeneous (i.e., identical) products likely will focus on price competition. Commodities like milk or oil, for example, are relatively homogeneous, and thus price is the sole determinant of consumer choice. However, if a firm can alter or tweak its product in a useful way (e.g., organic milk, fuel additives), then it might be able to charge more, and the degree of this differentiation can affect profits. Any stroll down the breakfast cereal aisle of a grocery store is a vivid reminder of the power of product differentiation-two firms, General Mills and Kellogg, dominate this market, yet dozens of different product offerings are sold at various prices.

As products become differentiated, price competition weakens. In many cases, sellers may very well be selling identical products (Whirlpool and Kenmore refrigerators are the same, as are Pert and Pantene shampoos) but will differentiate themselves by offering varying levels of customer service, return policies, product information or demonstration, colors, and so forth. ${ }^{53}$ Location and convenience can be powerful differentiators, even when selling something as homogenous as a gallon of milk.

The effect of differentiation on prices can be significant. At the extreme, two products can become so different that they no longer are substitutes for one another-while both made by General Motors, a Hummer is not really a viable substitute product for a Chevette. Accordingly, we should expect firms to attempt to differentiate their products as much as possible in order to soften price competition. ${ }^{54}$

As to whether consumers are better off as a result of product differentiation, the answer is "it depends." variety, so while differentiation results in higher prices, the value of increased variety may offset the reduction in consumer welfare from higher prices. ${ }^{56}$ So, there is a trade-off for consumers between variety and price. Differentiation is not always beneficial to consumers, and some firms may

53. Such services will only be offered if high prices or high volumes sufficiently raise profits to cover the additional costs.

54. In economic theory, this is known as the principle of maximum differentiation. STEPHEN MARTIN, ADVANCED INDUSTRIAL ECONOMICS 89 (2d ed. 2001).

55. In some cases, differentiation improves consumer welfare, while in others it may not. There is an optimal amount of differentiation. Most industrial economics textbooks cover this point. See, e.g., Don E. Waldman \& Elizabeth J. JenSEN, Industrial ORGANIZATION: THEORY AND PRACTICE 308 (1998).

56. First FCC Cable Competition Report, supra note 27, at para. 41. 
excessively differentiate in an effort to more aggressively soften price competition. One type of differentiation that would harm consumers is differentiation through sabotage, where one firm reduces the quality of a rival's product instead of improving its own quality. ${ }^{57}$ Product differentiation may also create entry barriers by forcing entrants to incur increased sunk advertising costs to win customers.

A recent study by the General Accounting Office ("GAO") on competition between cable television and DBS firms illustrates the importance of product differentiation. ${ }^{58}$ While both terrestrial and satellite multichannel video providers offer similar products, there are some meaningful forms of differentiation between the two. The differences in the delivery technology itself (i.e., intermodality) are not lost on consumers. Intuitively, we would expect that product differentiation between terrestrial rivals would be less than between terrestrial and DBS providers. The GAO study indicates that this is true. Econometric evidence presented in the study shows that satellite video providers reduce cable prices by about 5 percent, whereas the presence of a wireline, terrestrial video rival reduces prices by about 16 percent. ${ }^{59}$ The competitive effect of the "closer" rival is three times that of the satellite delivered video.

Other statistics in the study provide further support for the powerful impact of differentiation among multichannel video providers. For example, subscription to satellite services falls considerably ( 37 percent) when a terrestrial competitor exists. ${ }^{60}$ Even intermarket variations in the quality of the DBS service are shown to affect cable prices. The GAO study also concludes that consumers are more likely to subscribe to DBS service when the DBS provider is able to offer local broadcast stations. ${ }^{61}$ Limits on the ability of DBS providers to offer local broadcast channels is a classic example of public policy failing to make markets more conducive to competitive entry.

57. Product differentiation can alter the absolute quality as well as the relative quality among firms. Beneficial differentiation raises absolute quality (and may affect relative quality), whereas differentiation for sabotage only alters relative quality.

58. See General accountability Office, Direct Broadcast Satellite SUBSCRIBERSHIP HAS GROWN RAPIDLY, BUT VARIES ACROSS DIFFERENT TYPES OF MARKETS (Apr. 2005), available at http://www.gao.gov/new.items/d05257.pdf [hereinafter GAO REPORT ON DBS].

59. These price differences can be computed from the reported econometric results. For the DBS price change, a 100 percent reduction from the mean (22 percent) DBS penetration is equivalent to eliminating the DBS providers from the market. The coefficient is -0.0476 , which is roughly equal to 5 percent (the effect of DBS is measured as $-0.0476 \cdot 100 \%=$ -0.0476 ). The coefficient on a terrestrial overbuild is -0.1694 , and the percentage change in price is measured as exp(-0.1694) $-1=15.6 \%$.

60. See GAO REPORT ON DBS, supra note 58 , at 33.

61. See id. 


\section{Geographic Overlap}

Finally, profits are certainly related to the extent the "geographic" markets of rivals overlap. The question of geographic availability is particularly important for local communications networks, because the whole purpose of these networks is to provide communications services to where customers live or work. It does no good for a residential customer to be told that a new network's service is available across the street or down the block. As a result, the degree of overlap between competing networks has a significant impact on the degree of competition that may or may not exist between those networks.

The market boundary of communications networks is frequently referred to as "homes passed." We have observed that price competition and profits are related to geographic overlap of rivals. A 2005 article written by $\mathrm{T}$. Randolph Beard et al. shows that if the same price is charged across the entire market (i.e., price discrimination is prohibited), then the equilibrium price in cable television markets declines as the service areas of rival cable systems increasingly overlap. ${ }^{62}$ Thus, the larger the number of homes passed by both networks in a given market, the lower the equilibrium price will be. ${ }^{63}$

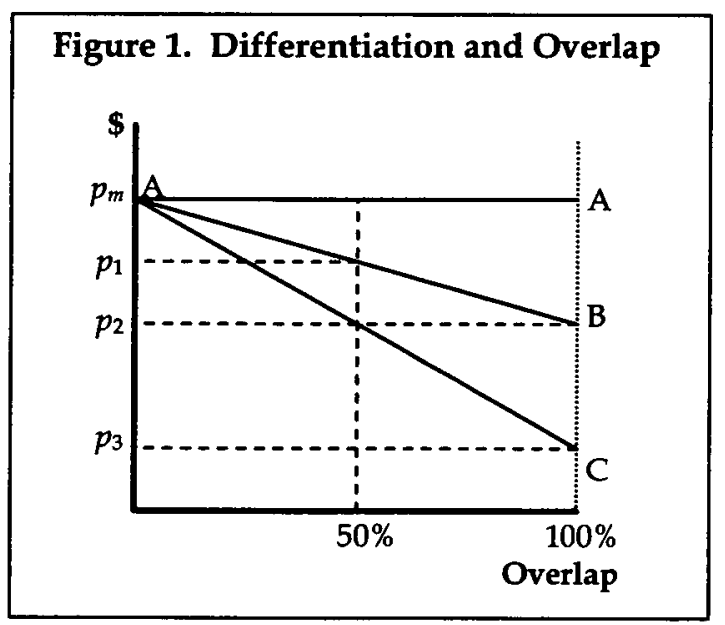

In Figure 1, we illustrate the effect on price of changes in overlap and product differentiation. We assume that with zero overlap, the incumbent firm is a monopolist and charges price $p_{m}$. Dollars are measured on the

62. See T. Randolph Beard et al., Fragmented Duopoly: A Conceptual and Empirical Investigation, $78 \mathrm{~J}$. BuS. 2377 (2005).

63. If different prices can be charged in the monopoly and contested segment, then a unique price for each segment will be charged (the monopoly price in one and the duopoly price in the other). 
vertical axis, and the percentage of rival system overlap is measured on the horizontal axis. First, consider the case where the services are so highly differentiated that consumers do not view them as substitutable in any way. In this case, we have the line labeled AA in the figure. Regardless of the overlap of the two networks, price remains at the monopoly level $\left(p_{m}\right)$. If the two services are highly substitutable, then we might have a priceoverlap relationship labeled AC. Now, price falls quickly as the overlap of the networks increases, with price $p_{2}$ at a $50 \%$ overlap and $p_{3}$ at $100 \%$ overlap. Finally, an intermediate case of product differentiation is indicated by the line labeled AB. At $100 \%$ overlap, price is $p_{2}$, whereas at $50 \%$ overlap, price is $p_{1}$. Note that price at $100 \%$ overlap with moderate differentiation (line $\mathrm{AB}$ ) is equal to the price for $50 \%$ overlap with very little differentiation (line $\mathrm{AC}$ ).

On the issue of system overlap, Beard and his colleagues provide strong evidence that overlap matters for cable prices. ${ }^{64}$ But the logic of Figure 1 is probably best demonstrated by evidence regarding the nature and consequences of competition between cable operators and DBS providers. As we mentioned above, the price effect in cable markets from a terrestrial cable rival is substantially larger than a DBS provider, because the satellite service is more differentiated from traditional cable service. On the issue of overlap, the GAO study shows that geographic conditions that adversely affect the ability of consumers to get DBS service raises cable prices. These geographic limitations on DBS effectively reduce system overlap in the same way that terrestrial systems may not serve identical geographic areas.

Overlap is likely to be an important feature of the emerging competition between cable and telephone carriers. The geographic areas of cable operators and telephone carriers do not always coincide, leaving the possibility for less than complete overlap of networks. Further, cable networks pass most, but not all homes. According to industry statistics, cable multichannel video service is available to $99 \%$ of U.S. homes with a television, and cable modem service is available to $96.8 \%$ of those homes. ${ }^{65}$ As a result, VoIP telephone services that use broadband connections, sold by either cable operators or other firms, are generally available. However, since only about $40 \%$ (and growing) of U.S. households actually subscribe to broadband services, such limited

64. See Beard et al., supra note 62.

65. Implementation of Section 19 of the Cable Television Consumer Protection and Competition Act of 1992, Twelfh Annual Report, FCC 06-11, para. 30 (Mar. 3, 2006) [hereinafter FCC Twelfth Cable Competition Report]; National Cable \& Telecommunications Association, Industry Statistics, http://www.ncta.com/ContentView.as px?contentId=54 (last visited Feb. 9, 2007) (reporting 107.8 million households passed by cable modem service out of 111.3 million television households). 
penetration serves to reduce the effective overlap of VoIP and traditional telephone service (the latter of which is ubiquitously available). ${ }^{66}$ It is not yet clear whether or not cable operators will require consumers to purchase a broadband connection in order to buy the cable operator's digital telephone service, nor is it clear how many cable operators will offer digital telephone service, but both of these decisions implicate the amount of overlap of the rival networks.

\section{B. Types of Entry Costs}

The other significant component of our entry equation constitutes entry costs. The higher the entry costs, other things constant, the fewer the number of firms in equilibrium. Entry costs $(e)$ can take a variety of forms, but entry costs are all fixed and sunk in our model. For a meaningful analysis of communications markets, we believe it is appropriate to divide entry costs into four major categories: (1) technological entry costs; (2) strategic entry costs; (3) regulatory entry costs; all of which may be offset by (4) spillovers. Table 5 summarizes the types of entry costs and their effect on the equilibrium number of firms $\left(N^{*}\right)$.

\begin{tabular}{lcl}
\hline Table 5. Types of Entry Costs & & \\
\hline \multicolumn{1}{c}{ Factor } & $\begin{array}{c}\text { Relationship } \\
\text { to e }\end{array}$ & $\begin{array}{c}\text { Effect } \\
\text { on } N^{*}\end{array}$ \\
\hline Increase in Technological Entry Costs & + & Fewer firms \\
Increase in Strategic Entry Costs & + & Fewer firms \\
Higher Regulatory Entry Costs & + & Fewer firms \\
Presence of Spillovers & - & More firms \\
\hline
\end{tabular}

As summarized in Table 5, three of the four forms of entry costs raise the cost of entry and, consequently, reduce $N^{*}$. Spillovers, which can be construed as a contra-cost, are actual reductions (or offsets) in entry costs caused by the use of a firm's existing assets to enter a related market. The larger the spillovers, the larger $N^{*}$ will be. As we describe later, however, spillovers need not be available to any and all firms, but instead are often limited to particular firms with existing assets.

66. See US Broadband Uptake Grows to $73.1 \%$ of Active Internet Users-July 2006 Bandwidth Report, WEBSITEOPTIMIZATION.COM, http://www.websiteoptimization.com/bw/0 607/ (last visited Feb. 9, 2007). 


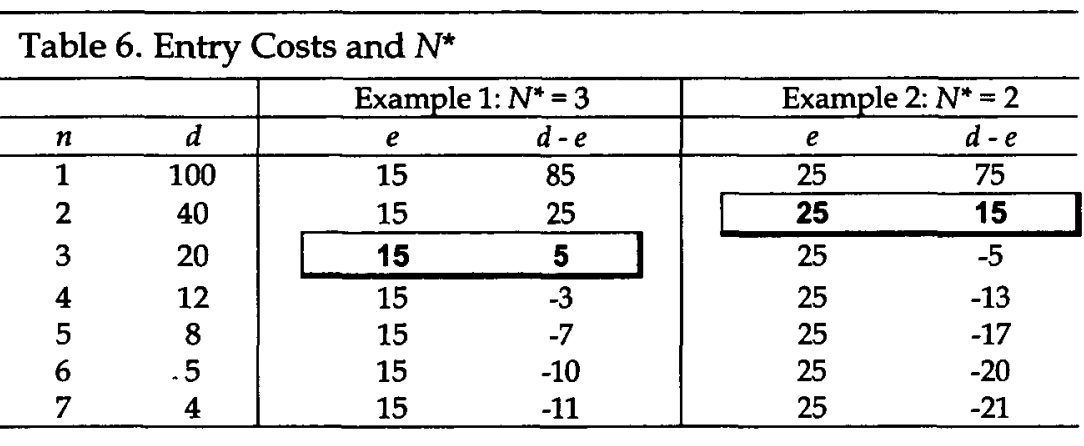

A numerical example illustrating the effect of entry costs on $N^{*}$ is provided in Table 6. Table 6 contains two examples. The first example is a repeat of the example from Table 1 , with entry costs of $\$ 15$. With entry costs of $\$ 15$, we have already shown that $N^{*}=3$. In Example 2, with entry costs of $\$ 25$, the second firm still finds it profitable to enter, with net profits of $\$ 15(=\$ 40-\$ 25)$. But, with higher entry costs, the third firm now realizes a negative net profit upon entry $(-\$ 5)$, so the third firm stays out. Now, the equilibrium is two firms $\left(N^{*}=2\right)$. As expected, the increase in entry cost has reduced the equilibrium number of firms. This example assumes only that entry costs rise. In the following sections, we provide examples as to what form these higher entry costs might take.

\section{Technological Entry Costs}

Technological entry costs are those entry costs inherent to providing the service. These costs include, for example, the cost of building a network, operating capital, advertising, and so forth. The technological entry costs required to construct a facilities-based telecommunications network to serve households are sizeable, and these costs alone are sufficient to render a highly concentrated industry equilibrium. It is also important to understand that technological entry costs are not simply network plant, but consist of any expenditure that is sunk. ${ }^{67}$

\section{Strategic Entry Costs}

Strategic entry costs are costs borne by a new entrant that exist solely because of an incumbent's strategic behavior. ${ }^{68}$ For example, the

67. See Why $A D C o$ ?, supra note 1 , at 14 (calculating that for every $\$ 1$ in network, telecommunications entrants spend $\$ 2$ of capital on other things, and most of these expenditures are probably sunk).

68. See First FCC Cable Competition Report, supra note 27, at para. 37 ("Incumbent systems may be able to use their incumbency to forestall or deter competitive entry via a 
incumbent may advertise excessively (creating differentiation) so that any entrant will have to do the same to attract customers. ${ }^{69}$ The incumbent may lobby local authorities to deny or delay the granting of rights-of-way construction permits. Finally, incumbent cable operators can "lock-up" popular programming via exclusive distribution contracts if the programming is transmitted via terrestrial means. ${ }^{70}$

Sometimes such costs can be imposed in a less-than-subtle fashionfor example, a marketing plan by a cable operator that offers customers discounts for taking down and returning DBS dishes (an action that would make subsequent DBS entry into that household more expensive). By raising entry costs in this way, the incumbent can deter entry. Strategic entry costs typically arise only in cases of sequential entry, where there is already an incumbent(s) in the market. In that situation, the incumbent is usually willing to increase its own costs or reduce its own profits (e.g., give a discount for a return of a DBS dish) in order to raise the entry costs of potential rivals. As observed by Thomas Schelling, " $[\mathrm{t}]$ he essence of [strategic entry costs] is some voluntary but irreversible sacrifice of freedom of choice. They rest on the paradox that the power to constrain an adversary may depend on the power to bind oneself . . .."71 In fact, we show later that an incumbent always has more incentive to deter entry than an entrant has to enter.

number of entry deterring strategies.") Incumbent behavior that raises entry barriers may be innocent or strategic. See Salop, supra note 31, at 335. For this analysis, we would place "innocent" barriers in the "technological entry costs" category.

69. See, e.g., James A. Dalton \& Stephen A. Rhoades, Growth and Product Differentiability as Factors Influencing Changes in Concentration, $22 \mathrm{~J}$. INDUS. ECON. 235, 235-40 (1974); Richard E. Caves \& Peter J. Williamson, What is Product Differentiation, Really?, 34 J. INDUS. ECON. 113, 128-29 (1985) ("a product-differentiation barrier to entry has at its heart information-based differentiation coupled with scale economies in sales promotion."). See also, First FCC Cable Competition Report, supra note 27, at para. 40 ("Product differentiation may constitute a barrier to entry if the extent of differentiation is sufficiently 'intense,' i.e., consumers perceive alternative products as poor substitutes for the differentiated product or service."). See generally John C. Hilke, Excess Capacity and Entry: Some Empirical Evidence, 33 J. INDUS. ECON. 233 (1984) (providing empirical evidence and a review of the theory).

70. See, e.g., James W. Olson \& Lawrence J. Spiwak, Can Short-Term Limits on Strategic Vertical Restraints Improve Long-Term Cable Industry Market Performance?, 13 CARDOZO ARTS \& ENT. L.J. 283 (1995), available at http://www.phoenix-center.org/library/ PROGRAMACCESS-PhoenixFormat.pdf. In some cases, blocking an entrant's access to programming is product differentiation through sabotage. Impeding access to existing programming does not increase the amount of programming available to consumers and thus has no effect on absolute quality. Rather, the restriction merely alters the relative qualities of the incumbent and entrant in favor of the incumbent.

71. See ThOMAS Schelling, The Strategy of Conflict 22 (1960). 


\section{Regulatory Entry Costs}

Regulatory entry costs are the result of rules and regulations enforced by government agencies. An excellent example of regulatory entry costs is cable franchise obligations, which often raise entry costs by burdening entrants with build out obligations and other rules that raise entry costs above what is necessary to provide service. In many cases, incumbents make their strategic entry costs more effective by using regulators to enforce duplication of such costs by entrants. Hazlett \& Ford (2001), for example, illustrate how level playing field laws enacted by some states deter entry in cable television markets by forcing entrants to match the entry costs of incumbent firms. ${ }^{72}$ As we will show later in the text, under such a law the incumbent cable operators have a powerful incentive to raise their own entry costs in order to deter future entry. We have already mentioned how public policy reduced the success of DBS providers by failing to address the issue of access to vital programming, thereby shrinking the market of the entrant.

\section{Spillover Effects}

Spillovers are reductions in entry costs arising from the ability of a firm to use its existing assets to provide service in a related market. For example, the local exchange companies were able to enter the data business by upgrading their networks to deliver data over copper wires (Digital Subscriber Line or "DSL"). Thus, these carriers did not have to build a complete data network from scratch, but simply "spilled over" their existing network into the data market with a marginal investment. Likewise, cable operators upgraded their one-way video networks to become two-way data networks. Similarly, the potential for broadband powerline ("BPL") "spills over" from the sunk network investment of electric utilities.

Plainly, another firm without a physical distribution network in local markets would have faced much higher entry costs to provide data service to businesses and households in a market. Today, because the FCC and the courts $^{73}$ have taken a strong stand toward reducing barriers to entry for cable modem service and VoIP - the cable companies' primary vehicle into telephony — cable operators are upgrading their networks to provide voice and other enhanced services over their data service. ${ }^{74}$ As such, spillovers

72. See Hazlett \& Ford, supra note 31.

73. See Nat'l Cable \& Telecomms. Ass'n v. Brand X Internet Servs., 545 U.S. 967 (2005).

74. See Joan Engebretson, Analysis: Cox Adopts VoIP at the Core, AMERICA's NETWORK, June 19, 2003, http://www.americasnetwork.com/americasnetwork/article/article Detail.jsp?id=61041 (several cable companies who pioneered entry into voice service, such 
are very important in communications markets, particularly as new technologies expand the capabilities of existing terrestrial networks. Importantly, spillovers are frequently limited to a few, existing firms, and this limitation gives rise to the concept of the "most likely entrant.",75

\section{MODERN COMMUNICATIONS POLICY AND THE ENTRY MODEL: FOUR APPLICATIONS}

Having explained the various components of our entry model, looking at both profits and entry costs, in this Part IV we apply the model in particular cases to show that policymakers can use the model to draw conclusions. As we do so, remember our basic tenet: firms will enter as long as it is profitable to do so, and the profitability of entry is determined by the difference between gross profits $(d)$ and entry costs $(e)$, where if $d \geq e$ there is entry. We provide four applications.

First, we illustrate how the entry model can be used to translate the concept of "convergence" into changes in industry structure. Convergence is an idea that has been bandied about in communications markets since the 1960s, when AT\&T argued in FCC proceedings that IBM mainframe computers were operating illegally as common carriers without a license. We show, using the logic of the entry model, what is required for "convergence" to have a meaningful impact on consumers and why convergence is only now becoming a reality in communications markets. We also show why convergence does not necessarily lead to a large number of competitors. Convergence typically affects only firms with existing assets, and thus the effect of convergence on industry structure will be limited.

Second, we illustrate why current limitations on the ability of telephone companies to offer video services over their networks will reduce the deployment of advanced communications networks.

Third, we illustrate the point that the incumbent always has a greater incentive to deter entry than the entrant has to enter. This analysis is highly relevant to the debate on cable franchising presently underway.

Finally, we use the entry model, slightly adjusted, to evaluate the prospect for collusion among telecommunications carriers and cable operators in a converged world. The entry model is exceptionally useful for

as Cox Communications, provided traditional switched telephony but are in the process of transitioning to VoIP).

75. See Applications of NYNEX Corp. and Bell Atlantic Corp. for Consent to Transfer Control of NYNEX Corp. and Its Subsidiaries, Memorandum Opinion and Order, 12 F.C.C.R. 19985, para. 6 (1997) (noting FCC concerns about the significant barriers to entry in the local telecommunications marketplace). 
this purpose and provides a compelling argument for why collusion should not be of great concern (at this time).

\section{A. Effect of Convergence on Industry Structure}

Convergence loosely implies the marriage of communications and computer technology, or "the coming together of the basic technology that supports voice communications, computer communications and, more recently, video and home entertainment . . . "76 With all forms of communications reduced to a digital transmission, a single digital network would be capable of delivering a wide array of communications services including voice, video, and data. Typically, commentators have expected convergence to increase competition by allowing all the various digital networks to provide a full suite of communications services. ${ }^{77}$

But consumers have not seen this form of "true convergence" just yet. In the last few years, rather than converging, communications products have oftentimes diverged, to the point that many well-heeled professionals now subscribe to landline phone, cable service, high-speed Internet, mobile phone, a separate BlackBerry wireless email account, and "On-Star" communications services in their cars - in addition to owning an iPod and TiVo unit. True convergence of services would create a spillover in which it would be profitable for a firm to sell multiple services over a common network. It is this spillover effect that would allow the industry to move to a more competitive structure. Convergence can come from unlikely sources - for example, it was expected that in 2005 mobile telephone makers would sell more cameras than the entire photo industry. ${ }^{78}$

The entry model, slightly adjusted, can be used to illustrate this fact. Say we have two monopolists serving markets A and B with each earning $\$ 100$. These firms might like to enter one another's markets, but doing so would require the construction of entirely new networks. Assume, for example, that entry costs are $\$ 50$ and the (gross) duopoly profit is $\$ 40$, so neither firm has an incentive to enter the other's market (because $\$ 40<\$ 50$ ). Thus, each firm enjoys the good life of an unchallenged monopolist. But this good life does not last long-a technological breakthrough allows each of the monopolists to leverage their existing

76. Steven Titch, Telephony, Defined and Redefined, TELEPHONY, May 1, 1995, at 5.

77. Id. ("Telephony was once only about a small group of carriers. Now it's about a universe of carriers ...") But cf. Jeanette Symons, Let's Not Go Broke Repaving the Last Mile, IEeE SPECTRum, Jan. 1, 2001, at 46 (on file with the Federal Communications Law Journal) ("It does not take much imagination to see that a single, converged network is the future of voice and data networking.").

78. Mobile Snaps: Are Camera-Phones Good News or Bad for the Photography Industry? ECONOMIST, July 3, 2003, available at $\mathrm{http}: / / \mathrm{www} . \mathrm{economist.com/business/disp}$ layStory.cfm?story_id $=1901134$. 
assets to provide service in the other firm's market. This technological breakthrough creates a spillover that reduces entry costs into their respective markets to $\$ 30$, but only for these two firms. Now, entry is feasible, since the $\$ 40$ duopoly profit exceeds the entry cost of $\$ 30$.

This example reveals a number of very important insights. First, absent the spillover, entry would not have occurred. Entry is an option solely because of a technological change (e.g., VoIP, DSL, fiber, and broadband over electric power line) that allowed each firm to leverage their existing assets to enter the other market. In the modern lingo of telecommunications, we have convergence-but the technological change only has an effect on industry structure when convergence creates a spillover large enough to alter equilibrium industry structure. Second, only those firms with assets affected by the spillover can afford to enter. Convergence does not mean that busloads of new firms can now enter the market-it means that firms already in another, related market can now enter and be profitable. As a result, there is some limit to the benefit of convergence if the generated spillover is restricted to a few firms.

Perhaps the most profound expression of convergence and spillovers today is the deployment of digital telephone service by cable operators. With the substantial improvements and innovations in VoIP over the past few years, the cable industry is shifting from offering analog, circuitswitched voice service to consumers in favor of leveraging their existing data networks to offer a digital, VoIP voice product. ${ }^{79}$ The analog voice market never really developed for the cable operators, but the relatively cheap deployment of digital voice likely will make cable a serious contender in the voice market. Moreover, not only has the FCC taken exclusive federal jurisdiction over $\mathrm{VoIP}^{80}$ (thus preventing a patchwork of regulations among the fifty states), but the FCC has explicitly preempted state laws that require new telephone entrants from any "build-out" requirements. ${ }^{81}$ As a result, a cable company can deploy VoIP to whatever customer base it pleases without regulatory consequence. The absence of a build-out requirement for VoIP greatly increases the potential profit for that service.

79. FCC Twelfth Cable Competition Report, supra note 65, at paras. 66-67.

80. See Vonage Holdings Corporation, Petition for Declaratory Ruling Concerning an Order of the Minnesota Public Utilities Commission, Memorandum Opinion and Order, 19 F.C.C.R. 22404 (2004).

81. See The Public Utility Commission of Texas, Memorandum Opinion and Order, 13 F.C.C.R. 3460, para. 13 (1997) (preempting "build-out" requirements for new local exchange entrants in Texas, noting that "build-out requirements are of central importance to competitive entry because these requirements impact the threshold question of whether a potential competitor will enter the local exchange market at all."). 


\section{B. Market Size and the Deployment of Advanced Communications} Networks

Nearly all existing networks must be upgraded to take full advantage of "convergence." Such upgrades can improve the quality of existing services offered by a firm, as well as allow the firm to expand into new services. One example of a radical network upgrade is fiber to the premises, where incumbent telephone companies are replacing their copper distribution plant with fiber-optic transmission paths that terminate at the customer's premises. These advanced networks offer exceptionally high bandwidth and can deliver a wide array of services. The value of network modernization is sizeable, and policymakers should facilitate the deployment of advanced networks.

We can use the entry model to illustrate how policymakers can encourage, and discourage, the deployment of advanced communications networks. Say there is a firm with a legacy network that is capable of delivering a service (e.g., voice) that renders $\$ 25$ in profits over the network's remaining economic life. A radical upgrade to the network would improve the quality of the existing service, increasing profits to $\$ 40$. The new network would also be capable of providing another service, also worth $\$ 40$ in profits. Say the upgrade costs $\$ 50$ in entry (or upgrade) costs. With gross profits of $\$ 80$ and an entry cost of $\$ 50$, the firm chooses to upgrade the network and earns a profit of $\$ 30$ (a $\$ 5$ increase over the status quo of $\$ 25$ ).

But what if policymakers restrict the firm's access to the new market? If policy blocks entry into the new market altogether, then the gain to the upgrade of $\$ 15(=\$ 40-\$ 25)$ is far below the entry cost of $\$ 50$. There is no profit in the upgrade, so the upgrade is shelved. Even if policy allows entry, but tacks on an additional $\$ 10$ in entry costs, then the firm chooses not to upgrade the network (the gain is only $\$ 20=\$ 80-\$ 50-\$ 10<\$ 25$ ).

These examples illustrate that with convergence policymakers must be aware of how entry barriers in related markets can affect primary markets. If network modernization is to occur, then regulatory entry barriers that exist in any market that the network may serve must be eliminated to the greatest extent possible. Similarly, policymakers should not facilitate the creation of strategic entry barriers by incumbent firms.

\section{Deterring Entry by Treating Entrants and Incumbents Equally}

As noted above, the Federal Communications Commission has explicitly found that the "local franchise process is, perhaps, the most important policy-relevant barrier to competitive entry in local cable 
markets." 82 Notwithstanding, it is often argued, in the interests of "fairness," that new entrants should have to overcome and face the same hurdles that an incumbent has faced. We are currently seeing this argument develop in the context of cable franchise and build-out requirements, where incumbent cable companies are insisting that telephone companies that seek to sell video services commit to the same franchise process and buildout requirements that the incumbent cable company had to face.

But the sequence of entry is critical and an asymmetry arises from the differential treatment of sunk costs by the incumbent and the entrant. To the incumbent, entry costs are sunk and bygone and thus will not affect marginal decisions. However, to the entrant, sunk entry costs are marginal costs (i.e., fixed costs are neither fixed nor sunk until incurred), and thus play a key role in decisions. The incumbent, therefore, considers these entry costs much differently than the entrant simply because the incumbent need not incur them in the future, and what he has spent is sunk. Sunk costs give the incumbent a "first mover" advantage over entrants. The presence of a "first mover" advantage means that requiring a new entrant to bear an entry cost simply because the incumbent has already borne it will have the effect of deterring entry substantially, even if such costs did not deter the incumbent from offering service.

To illustrate the first mover advantage, we simplify the entry model to a case of two firms-an incumbent and one entrant. The incumbent monopolist makes a profit of $m$. If entry occurs, then both the incumbent and entrant make the duopoly profit $d$. Entry requires entry costs equal to $e$, so post-entry the incumbent has profits of $d$ and the entrant has profits of $d-e$ (a numerical example will be provided later in the text). Since the monopoly profit is the largest possible profit, it must be true that $2 d-e<$ $m$; in other words, the summed profits of the incumbent and the entrant are less than the monopoly profit (even with perfect collusion due to the presence of $e$ ).

Assume that the entrant's post-entry profit is positive $(d-e>0)$ so that it plans to enter. Knowing this, the incumbent decides to voluntarily incur some sunk expenditure $b$ that the entrant must match. The entrant's entry costs are now $e+b$; post-entry profit for the incumbent is $d-b$ and for the entrant is $d-e-b$.

We have assumed that without the extra entry costs $b$, the entrant would enter. Now, the question is whether the incumbent has an incentive to make $b$ large enough to deter entry. The answer is yes.

82. See First FCC Cable Competition Report, supra note 27, at para. 43 (emphasis added). 
If entry occurs, then the monopolist's lost profits are $m-d$. The gain to the entrant from entering the market is $d-e$. But, since $2 d-e<m$, the monopolist loses more than the entrant gains. ${ }^{83}$ Thus, the monopolist will be willing to expend more of its profits to deter entry than the entrant can gain in profit by entering. By setting $b=d-e+g$ (where $g$ is just a very small number), the monopolist can deter entry and come out ahead.

A numerical example may help. Let the monopoly profit $(m)$ be $\$ 100$, the duopoly profit $(d)$ be $\$ 40$, and entry costs $(e)$ be $\$ 30$. Since the duopoly profit exceeds entry costs $(40-30=10>0)$, the entrant plans to enter. Prior to entry, the incumbent incurs a sunk expenditure of $\$ 11$ that the entrant must match. Now, the entrant's net gain from entry is $-\$ 1(40-30-$ $11=-1<0$ ), so the entrant stays out. Is the incumbent better off? Yes. By deterring entry, the monopolist now earns $\$ 89(\$ 100-\$ 11)$. Had entry occurred, the monopolist's profit would be $\$ 40$, so the monopolist chooses to deter entry. If the entrant must match the sunk expenditures of the incumbent, then it will always be rewarding to the incumbent to deter entry, even if that action increases the costs of the incumbent.

Given the condition on joint profits, if entry costs of the entrant must match exactly (or be larger) than the incumbent, then the incumbent always has more incentive to deter entry than an entrant has to enter the same market. An extreme example can illustrate this point. Say the incumbent and entrant plan to collude post-entry so that expected profits are $\$ 50$ (i.e., $\$ 100 / 2)$. The entrant needs to incur a technological entry cost of only $\$ 1$. So, we have a situation with the highest possible post-entry profits and nearly no entry costs. The post-entry profit of the incumbent is $\$ 50$, and the entrant makes $\$ 49(=\$ 50-\$ 1)$. Note that if the incumbent spends $\$ 49.01$ in sunk costs that the entrant must match, the incumbent's profit rises to $\$ 50.99$, and the entrant's profit falls to $-\$ 0.01$. Clearly, it pays for the incumbent to deter entry by raising strategic entry costs, since the incumbent is more profitable without than with entry.

There are three important lessons to be learned from this example, all of which arise from the fact that incumbents and entrants are not equals. First, policymakers should recognize that incumbents can incur more sunk costs than entrants because their profits are higher. In fact, many cable systems were constructed during the era of exclusive franchising, in which a cable company incurred these costs at a time when it was guaranteed a monopoly over cable services in the area. A firm offered a monopoly would readily propose or agree to a higher entry cost than it otherwise would have agreed to in a competitive environment. Second, policymakers

83. We can rearrange the condition on joint profits to be: $d+d-e<m$, or more directly, $d-e<m-d$. 
should avoid any rule or regulation that requires, out of some concept of fairness, entrants to match the sunk expenditures of incumbents. Incumbents and entrants view sunk entry costs differently. This is due to the very nature of sunk costs and sequential entry-once the first firm (the incumbent) has incurred those costs, those costs are sunk and essentially irrelevant to that firm's subsequent business decisions. For the second firm (the prospective entrant), sunk costs are a marginal cost and before spending them, the prospective entrant will consider other uses of those funds. The incumbent and the entrant will treat sunk costs in different ways: equal treatment of unequals is not equal treatment. Third, markets with sunk costs have a technological bias against entry, thus providing justification for policymakers to err on the side of making entry easier and less expensive, rather than harder and more costly.

\section{What Entry Says About Collusion}

When faced with a concentrated market, probably the first concern that comes to the mind of a policymaker is the threat of collusion. We noted in Part III.A.2 at Table 4 that it is easy to confuse collusion with intense price competition, and this confusion arises primarily from a strict adherence to the traditional view that the intensity of price competition rises with the number of firms. Once the effects of sunk costs are incorporated into the model of competition, such a simple notion of competition no longer tells the complete story. But the entry model has more to say about collusion.

Consider the game of reciprocal entry from the previous section on convergence. We have two monopolists serving markets $A$ and $B$ with each earning $\$ 100$. Entry costs are $\$ 50$ and the (gross) duopoly profit is $\$ 40$, so neither firm has an incentive to enter either market. A technological breakthrough allows each of the monopolists to leverage his existing assets to provide service in the other firm's market, so that entry costs for each of these firms falls to $\$ 30$. Entry is now feasible for both firms.

Assume both firms enter each other's markets. The incumbents earn post-entry profits of $\$ 40$ in their own market and $\$ 10$ in profits from the entered market $(=40-30)$, for a total of $\$ 50$ in profit for each firm. After entry, their profits have fallen from $\$ 100$ to $\$ 50$. In retrospect, reciprocal entry, obviously, was not a very good idea. Despite the technological breakthrough and spillover effect of convergence, firms A and B would have been much better off had they ignored the development and stayed in their own respective markets. If $A$ and $B$ were the only two firms for which the spillover effect of convergence were available (that is, a new firm, C, could not reap those benefits), then there is every reason to believe that this collusion could be sustainable in the long term. 
In our example, the collusive outcome is to ignore convergence and not enter. The converse is also true-if we observe reciprocal entry, then that entry is solid evidence that collusion is not occurring. The easiest time for firms to collude is before they enter one another's markets. Today, we observe cable operators moving into the telephone business and the telephone companies moving aggressively into the video business (though the latter is hindered by franchising), and this simple observation alone is strong evidence that collusion is not present. ${ }^{84}$ Thus, at present, we believe that policymakers should not focus on the possibility of collusion, at least in those markets where reciprocal entry is observed. ${ }^{85}$

An interesting twist to this example of reciprocal entry is one-sided entry. One-sided entry occurs if only one firm experienced the spillover. In this scenario, the advantaged firm would enter the rival market and increase profits to $\$ 110$ ( $\$ 100$ from the monopoly plus $\$ 10$ from the rival market). The profits of the incumbent in the rival market fall to the duopoly level of $\$ 40$. Since only one firm experienced the spillover, there is no threat of retaliatory entry by the firm unaffected by the spillover. ${ }^{86}$ Perhaps the cable industry's venture into voice services was motivated, in part, by the assurances that cable franchising would effectively deter retaliatory entry by telephone carriers.

\section{CONCLUSION}

U.S. telecommunications policy now aims to rely upon facilitiesbased and "intermodal competition" to benefit consumers in voice, video, and data markets. History suggests that a reliance on facilities-based competition implicitly embraces highly concentrated markets, where few firms vie for the patronage of customers. This Article demonstrates that in order to have vibrant intermodal, facilities-based competition in all communications markets, policymakers must focus their attention on the consequences of their actions on the entry and expansion decisions of firms into related markets. This task is simple and intuitive-if policymakers want there to be more entry, they should focus on figuring out how to make entry more profitable without harming consumers. In particular, policymakers should implement policies that increase gross profits (e.g., allow firms to sell as many services as possible), reduce entry costs (e.g., remove franchising requirements and "regulatory symmetry"

84. Reciprocal entry might be profitable if the markets are already reasonably competitive (i.e., there is little to give up if reciprocal entry occurs).

85. Once market shares stabilize, probably five to seven years out, then policymakers may wish to revisit the question of collusion.

86. The collusive outcome would involve the incumbent without a spillover paying the other firm to stay out (an amount equal to something between $\$ 10$ and $\$ 60$ ). 
requirements), or, better yet, both. Assuming policymakers can increase post-entry profits in this way, it is not unreasonable to expect that facilitiesbased firms will invest and/or upgrade their networks to take advantage of true technological convergence and compete vigorously on both price and product differentiation-a result that is clearly beneficial to U.S. consumers. 
